\title{
Evidence for cell-density-dependent regulation of catalase activity in Rhizobium leguminosarum bv. phaseoli
}

\author{
Ansley J. Crockford, Georgina A. Davis and Huw D. Williams \\ Author for correspondence: Huw D. Williams. Tel: +44 171594 5383. Fax: +44 1715842056. \\ e-mail: h.d.williams@ic.ac.uk
}

Department of Biology, Imperial College of Science, Technology and Medicine, Prince Consort Road, London SW7 2BB, UK

\begin{abstract}
Pretreatment of Rhizobium leguminosarum bv. phaseoli cultures with low, non-lethal levels of $\mathrm{H}_{2} \mathrm{O}_{2}$ led to them becoming more resistant to killing by higher concentrations of this oxidant. The sensitivity of $R$. leguminosarum to $\mathrm{H}_{2} \mathrm{O}_{2}$-mediated oxidative stress varied with the growth phase of the cultures. Stationary phase cells were many times more resistant to killing by $3 \mathrm{mM} \mathrm{H}_{2} \mathrm{O}_{2}$ than exponentially growing cultures. Unexpectedly, the catalase activity of cultures was found to rise to a maximum in the early-exponential growth phase and rapidly fall to a minimum during late-exponential growth. Further investigation showed that the induction and subsequent repression of catalase activity in exponential cultures is a cell-density-dependent phenomenon which appears to be controlled by the accumulation of extracellular compound(s) in the growth medium at high cell densities. In this respect, control of catalase in R. leguminosarum resembles a number of other cell-density-regulated phenomena in bacteria which are controlled by the accumulation of extracellular molecules: the best studied example of this quorum sensing is the control of bacterial bioluminescence by the lux autoinducer. Preliminary data indicated that this extracellular component is a non-proteinaceous, heatstable molecule.
\end{abstract}

Keywords: quorum sensing, oxidative stress, nitrogen fixation, oxygen

\section{INTRODUCTION}

Molecular oxygen is both beneficial and detrimental to aerobic organisms. In acting as a terminal electron acceptor, it provides enormous advantages in terms of energy generation but it is also universally toxic. This toxicity is largely due to the intermediates of oxygen reduction: hydrogen peroxide $\left(\mathrm{H}_{2} \mathrm{O}_{2}\right)$, superoxide $\left(\mathrm{O}_{2}^{-}\right)$ and hydroxyl free radicals, as well as singlet oxygen (Halliwell \& Gutteridge, 1989). Any organism that benefits from oxygen has to protect itself from these reactive oxygen species (Chance et al., 1978; Fridovich, 1978; Halliwell \& Gutteridge, 1989) which, if present, can oxidize fatty acids, initiating lipid peroxidation (Storz et al., 1990), oxidize proteins (Brot et al., 1981) and damage DNA (Demple \& Linn, 1982; Levin et al., 1982). Consequently, aerobically growing organisms have evolved numerous defence mechanisms against these toxic oxygen species. These include enzymic mechanisms such as catalases and peroxidases for removal of $\mathrm{H}_{2} \mathrm{O}_{2}$, or superoxide dismutases for destruction of superoxide, as well as non-enzymic antioxidants such as glutathione, ascorbic acid and uric acid (Halliwell \& Gutteridge, 1989).

The response of bacteria to oxidative stress has been most extensively studied in the enteric bacteria Escherichia coli and Salmonella typhimurium (Demple, 1991; Farr \& Kogama, 1991; Storz et al., 1990). When they are pretreated with non-lethal doses of $\mathrm{H}_{2} \mathrm{O}_{2}$ they adapt, becoming more resistant to killing by subsequent treatment with lethal doses of $\mathrm{H}_{2} \mathrm{O}_{2}$ (Christman et al., 1985; Demple \& Halbrook, 1983). Similarly, E. coli can adapt to stress from superoxide generated by pretreatments with low levels of menadione or paraquat (Greenberg \& Demple, 1989). A number of proteins (and their genes) which form part of the oxidative stress response have been identified including catalase and superoxide dismutase as well as DNA repair enzymes such as exonuclease $I V$, DNA polymerase, $\operatorname{rec} B C$ nuclease and $\operatorname{Rec} A$ which are important in repairing DNA damaged as a consequence of oxidative stress (Demple, 1991; Farr \& Kogoma, 1991). Genes involved in control of the oxidative stress response have also been identified, for example the induction of 
nine proteins in response to $\mathrm{H}_{2} \mathrm{O}_{2}$ stress is under the positive control of the oxyR gene product (Christman et al., 1989). It is apparent that there is considerable overlap between different bacterial stress responses (Nystrom, 1993; Siegle \& Kolter, 1992). $\mathrm{H}_{2} \mathrm{O}_{2}$-adapted enteric bacteria become more resistant to heat and osmotic challenge and there is overlap between the proteins synthesized during oxidative stress and those induced by carbon- or nitrogen-starvation in E. coli (Christman et al., 1985; Siegle \& Kolter, 1992).

Little is known about the response of symbiotic nitrogenfixing bacteria to environmental stress, their ability to adapt to and survive in adverse soil conditions and how stress might affect their propensity to form effective, nitrogen-fixing symbioses with leguminous plants (Graham, 1992). In this report, we describe a study of the response of Rhizobium leguminosarum bv. phaseoli to $\mathrm{H}_{2} \mathrm{O}_{2}$ stress and discuss its possible significance to nitrogenfixing bacteroids in root nodules.

\section{METHODS}

Bacteria and growth conditions. Rbizobium leguminosarum biovar phaseoli strain 4292 kindly provided by Dr Allan Downie (John Innes Centre, Norwich, UK) was used in this work. It was grown in YEM medium (Vincent, 1970) consisting of $\left(\mathrm{g} \mathrm{l}^{-1}\right)$ yeast extract $(0 \cdot 4), \mathrm{K}_{2} \mathrm{HPO}_{4}(0 \cdot 5), \mathrm{NaCl}(0 \cdot 1), \mathrm{MgSO}_{4} .7 \mathrm{H}_{2} \mathrm{O}$ $(0 \cdot 2)$, mannitol (10), or TY medium comprising ( $\left.\mathrm{g} \mathrm{l}^{-1}\right)$ Bactotryptone (5), yeast extract (3), $\mathrm{CaCl}_{2} \cdot 6 \mathrm{H}_{2} \mathrm{O}(1 \cdot 3)$. For solid medium, agar was added at $15 \mathrm{~g} \mathrm{l}^{-1}$.

Culture methods for $\mathrm{H}_{2} \mathrm{O}_{2}$ treatment and adaptation experiments. $R$. leguminosarum was inoculated into YEM medium and grown with shaking at $30^{\circ} \mathrm{C}$ to $\mathrm{OD}_{600} 0 \cdot 2\left(4 \times 10^{8}\right.$ c.f.u. $\left.\mathrm{ml}^{-1}\right)$. Aliquots $(5 \mathrm{ml})$ of the culture were transferred into sterile tubes and $\mathrm{H}_{2} \mathrm{O}_{2}$ added to the desired final concentration and incubated as before. Samples were taken immediately prior to and periodically after $\mathrm{H}_{2} \mathrm{O}_{2}$ addition, diluted in YEM minus mannitol and plated onto TY agar to monitor cell viability. Colonies were counted after $2 \mathrm{~d}$ incubation at $30^{\circ} \mathrm{C}$. For $\mathrm{H}_{2} \mathrm{O}_{2}$ adaptation experiments overnight cultures were used to inoculate $50 \mathrm{ml}$ YEM to initial $\mathrm{OD}_{600} 0 \cdot 01$. When the culture had grown to $\mathrm{OD}_{600} 0 \cdot 2, \mathrm{H}_{2} \mathrm{O}_{2}$ was added to a final concentration of $200 \mu \mathrm{M}$. After the pretreated cells had been incubated for $2 \mathrm{~h}$ a sample was taken to determine culture viability and then $\mathrm{H}_{2} \mathrm{O}_{2}$ was added to a final concentration of $3 \mathrm{mM}$ and the culture sampled at intervals for viable counting.

Determination of catalase activity of growing cultures. Because of the slow growth rate of $R$. leguminosarum in YEM and our desire to follow its catalase induction kinetics by sampling frequently during growth, for convenience we often set up a number of identical experimental flasks and staggered their inoculation. This meant that regular samples at $4 \mathrm{~h}$ intervals could be taken over the $100 \mathrm{~h}$ of a typical experiment by sampling different flasks at different stages following inoculation. This was the case for the experiment described in Fig. 3. For assay of catalase activity, culture samples were centrifuged at $10000 \mathrm{~g}$ for $10 \mathrm{~min}$ and the resultant cell pellet was washed twice in $50 \mathrm{mM}$ potassium phosphate buffer ( $\mathrm{pH} \mathrm{7.0)}$ before being resuspended in the same buffer prior to assay. Catalase activity was determined by measuring $\mathrm{O}_{2}$ evolution from cell suspensions following addition of $0.5 \mathrm{mM} \mathrm{H}_{2} \mathrm{O}_{2}$ as described by Rorth \& Jensen (1967), using a Clark-type oxygen electrode. Catalase units are expressed as $\mu \mathrm{mol} \mathrm{O}_{2}$ evolved $\mathrm{min}^{-1}$ (mg protein $)^{-1}$. Catalase activity of $R$. leguminosarum cell-free extracts (prepared as described by Williams et al., 1990) in polyacrylamide gels was localized as described previously (Clare et al., 1984).

Preparation of spent culture medium. R. leguminosarum cultures were grown to late-exponential phase in YEM $\left(\mathrm{OD}_{600} 0 \cdot 8\right.$, $1 \times 10^{9}$ c.f.u. $\mathrm{ml}^{-1}$ ). Cells were removed by centrifuging twice at $10000 \mathrm{~g}$ for $10 \mathrm{~min}$; the supernatant fraction was collected and filter sterilized through a $0 \cdot 2 \mu \mathrm{m}$ filter. The spent culture medium was then used immediately for experiments.

Protein assay. Protein was determined by the method of Markwell et al. (1978) using bovine serum albumin $\left(2 \mathrm{mg} \mathrm{ml}^{-1}\right)$ as the standard.

\section{RESULTS}

\section{Survival and adaptation of $R$. leguminosarum bv. phaseoli after treatment with $\mathrm{H}_{2} \mathrm{O}_{2}$}

To determine the effect of various concentrations of $\mathrm{H}_{2} \mathrm{O}_{2}$ on the viability of $\mathrm{R}$. leguminosarum, cultures were grown to mid-exponential phase $\left(4 \times 10^{8}\right.$ c.f.u. $\left.\mathrm{ml}^{-1}\right)$, treated


Fig. 1. Sensitivity of $R$. leguminosarum to killing by $\mathrm{H}_{2} \mathrm{O}_{2}$. Cells were grown exponentially in YEM medium to $O_{600} \mathbf{0 . 2}$ $\left(4 \times 10^{8}\right.$ c.f.u. $\left.\mathrm{ml}^{-1}\right)$ which represents $100 \%$ survival. Cells were challenged with various concentrations of $\mathrm{H}_{2} \mathrm{O}_{2}$ as described in Methods and samples taken periodically, diluted and plated onto TY medium to determine cell viability. The $\mathrm{H}_{2} \mathrm{O}_{2}$ concentrations were as follows. (a) $\square, 0 \mathrm{mM} ; \square, 200 \mu \mathrm{M} ; O$, $2 \mathrm{mM}$. In (b) $\square, 3 \mathrm{mM} ; \square, 5 \mathrm{mM}$. Data points are the means of duplicates from a representative experiment. 


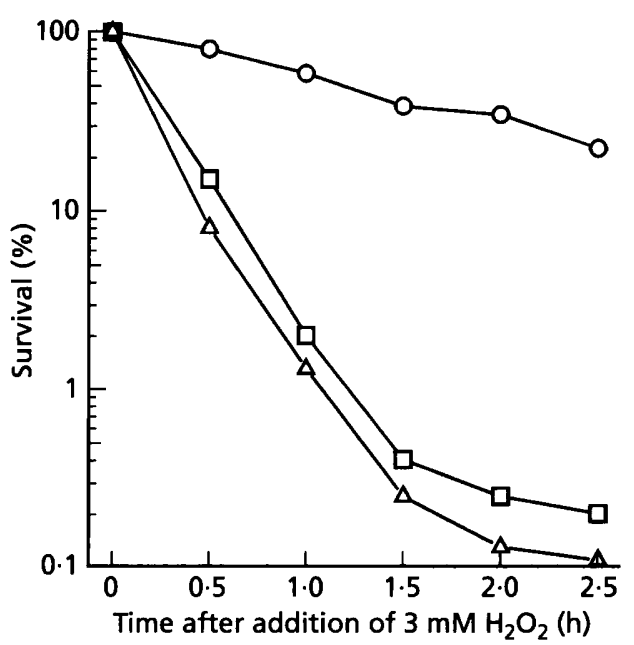

Fig. 2. Adaptation of $R$. leguminosarum to $\mathrm{H}_{2} \mathrm{O}_{2}$. $R$. leguminosarum was grown as described for Fig. 1 and then treated with $200 \mu \mathrm{M} \mathrm{H}_{2} \mathrm{O}_{2}$ for $2 \mathrm{~h}$ in the presence and absence of chloramphenicol $\left(100 \mu \mathrm{g} \mathrm{ml}^{-1}\right)$. After $2 \mathrm{~h} \mathrm{H}_{2} \mathrm{O}_{2}$ was added to all cultures to a final concentration of $3 \mathrm{mM}$; samples were taken periodically, diluted and plated on TY medium to determine cell viability. $\square$, No pretreatment; $\triangle$, pretreated in the presence of chloramphenicol; $O$, pretreated in the absence of chloramphenicol. Data points are the means of duplicates from a representative experiment.

with various concentrations of $\mathrm{H}_{2} \mathrm{O}_{2}$ and samples taken at intervals after $\mathrm{H}_{2} \mathrm{O}_{2}$ addition for viable counting. Low concentrations $(200 \mu \mathrm{M}-2 \mathrm{mM})$ resulted in characteristic $\mathrm{V}$-shaped survival curves (Fig. 1a) while exponentially growing cells were rapidly killed by 3 and $5 \mathrm{mM} \mathrm{H}_{2} \mathrm{O}_{2}$ (Fig. 1b). This implied that lower concentrations of $\mathrm{H}_{2} \mathrm{O}_{2}$ allowed the cells to undergo a period of adaptation to the $\mathrm{H}_{2} \mathrm{O}_{2}$ and, once this was complete, growth resumed at a similar rate to the untreated culture. This potential adaptive response was further examined by treating exponentially growing cells with a non-lethal concentration of $\mathrm{H}_{2} \mathrm{O}_{2}, 200 \mu \mathrm{M}$ for $120 \mathrm{~min}$, and then challenging them with $3 \mathrm{mM} \mathrm{H}_{2} \mathrm{O}_{2}$ and following culture viability. The results in Fig. 2 show that cells pretreated with $200 \mu \mathrm{M} \mathrm{H}_{2} \mathrm{O}_{2}$ were much more resistant to killing by $3 \mathrm{mM} \mathrm{H} \mathrm{H}_{2} \mathrm{O}_{2}$ than untreated cells. Cells treated with $200 \mu \mathrm{M} \mathrm{H}_{2} \mathrm{O}_{2}$ in the presence of the protein synthesis inhibitor chloramphenicol did not acquire resistance to $3 \mathrm{mM} \mathrm{H}_{2} \mathrm{O}_{2}$, indicating that de novo protein synthesis is required for adaptation of $\mathrm{R}$. leguminosarum to $\mathrm{H}_{2} \mathrm{O}_{2}$.

\section{Adaptation to $\mathrm{H}_{2} \mathrm{O}_{2}$ indicates induction of catalase activity}

In S. typhimurium, the adaptive response to $\mathrm{H}_{2} \mathrm{O}_{2}$ stress involves a four- to fivefold induction of catalase activity (Christman et al., 1985). As catalase is one of the major enzymes for removing $\mathrm{H}_{2} \mathrm{O}_{2}$, we looked at the effect of adaptive concentrations of $\mathrm{H}_{2} \mathrm{O}_{2}$ on $R$. leguminosarum catalase levels. Exponential cultures treated with $200 \mu \mathrm{M} \mathrm{H} \mathrm{H}_{2} \mathrm{O}_{2}$ typically showed a moderate increase in catalase activity compared to the untreated control: $1 \cdot 1 \mu \mathrm{mol} \mathrm{O}{ }_{2} \min ^{-1}(\mathrm{mg} \text { protein })^{-1}$ versus
$0.6 \mu \mathrm{mol} \mathrm{O}_{2} \min ^{-1}$ (mg protein $)^{-1}$. This was also observed by catalase-activity-staining native PAGE gels of $R$. leguminosarum cell-free extracts : more intensely staining catalase bands were observed with samples from $\mathrm{H}_{2} \mathrm{O}_{2}-$ treated cultures (data not shown).

\section{Catalase activity reaches a maximum during the early-exponential growth phase}

It was noticed during the course of measuring catalase activities that levels seemed to fall off in stationary phase cultures. Therefore, we investigated the kinetics of catalase induction in $\mathrm{R}$. leguminosarum in the presence and absence of $\mathrm{H}_{2} \mathrm{O}_{2}$. Fig. 3 shows catalase levels throughout the growth of cultures in the presence and absence of $200 \mu \mathrm{M} \mathrm{H}_{2} \mathrm{O}_{2}$. It is clear that while the absolute levels of catalase activity are higher in the culture to which a nonlethal $\mathrm{H}_{2} \mathrm{O}_{2}$ concentration has been added (Fig. 3b), the kinetics of catalase induction were similar to the untreated culture (Fig. 3a). It was striking that catalase activity reached a maximum in the early- to mid-exponential growth phase and subsequently declined during the midto late-exponential phase (Fig. 3a). In the presence of $\mathrm{H}_{2} \mathrm{O}_{2}$ (Fig. 3b), the decline in catalase activity was not quite so rapid, but the general trend was similar. This is an interesting result particularly as it is quite different to the kinetics of catalase induction observed in $E$. coli and $S$. typhimurium, where the catalase activity was found to rise through exponential phase to a maximum in stationary phase (Finn \& Condon, 1975; Hassan \& Fridovich, 1978). In R. leguminosarum, the catalase activity fell to a minimum in late-exponential growth and remained at this low level during stationary phase. This trend was confirmed by catalase activity staining of polyacrylamide gels of cell extracts from cultures sampled at different stages during growth. Catalase stained gels show three catalase isoenzymes (Fig. 3c) and although changes are seen in all bands between different sample times they are most easily seen for the bands labelled 2 and 3 . Between $8 \mathrm{~h}$ and $16 \mathrm{~h}$ an increase in the intensity of these bands is seen followed by a progressive decrease in their staining from $16 \mathrm{~h}$ onwards. This correlates very well with the changes in catalase activity through growth.

\section{Sensitivity of $R$. leguminosarum to $\mathrm{H}_{2} \mathrm{O}_{2}$ is dependent on the growth phase}

The data in Fig. 4 show the effect of growth phase on the sensitivity of $\mathrm{R}$. leguminosarum to killing by $3 \mathrm{mM} \mathrm{H}_{2} \mathrm{O}_{2}$. The exact results of this experiment were somewhat variable but the trend was very clear; stationary phase cells are between 10 and 200 times more resistant to $\mathrm{H}_{2} \mathrm{O}_{2}$ than exponentially growing cells. This result implies that even though catalase levels fall off during mid-exponential phase, an alternative, more effective means of protecting cells against $\mathrm{H}_{2} \mathrm{O}_{2}$ is induced in late-exponential and stationary phase.

\section{Catalase activity is dependent on cell density}

A possible explanation for the kinetics of catalase induction is that catalase activity is cell-density regulated. 

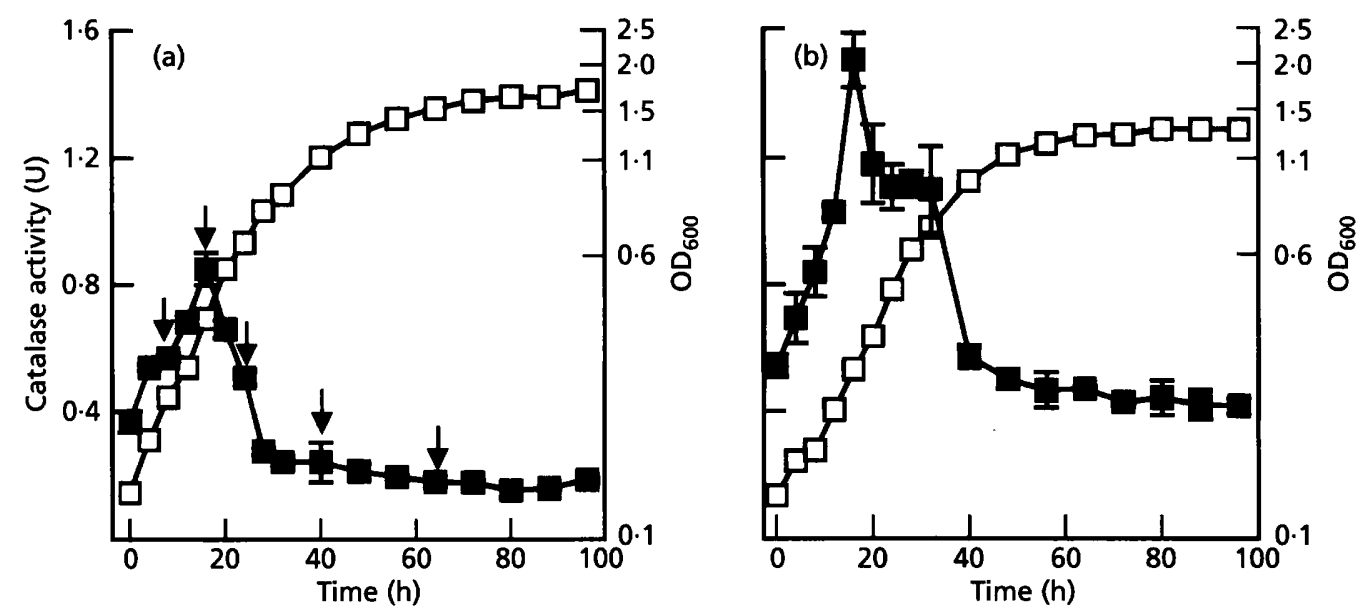

(c)

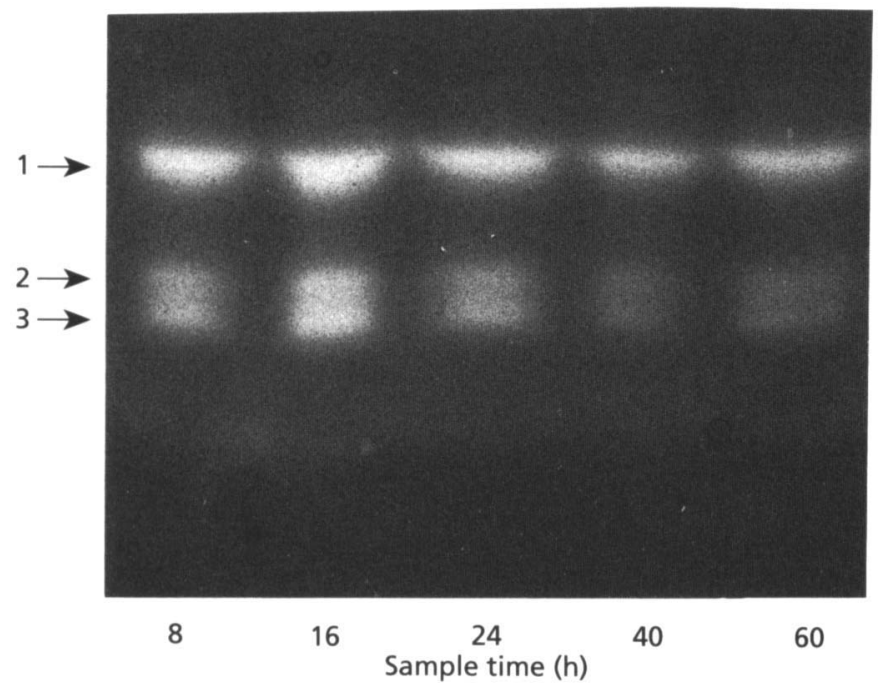

Fig. 3. Induction of catalase activity by $R$. leguminosarum during growth in YEM medium in the presence (b) and absence (a) of $\mathrm{H}_{2} \mathrm{O}_{2}$. Cultures were inoculated to a density of $2 \times 10^{8}$ c.f.u. $\mathrm{ml}^{-1}$. Samples were taken for determination of $\mathrm{OD}_{600}(\square)$ and catalase activity $(\square)$ as described in Methods. In (b), $200 \mu \mathrm{M} \mathrm{H}_{2} \mathrm{O}_{2}$ was added to the culture $4 \mathrm{~h}$ after inoculation. Error bars represent the standard deviation of assays done in triplicate. The arrows in (a) indicate the time points at which cell samples were taken for analysis of catalase isoenzyme content, the results of which are shown in the catalase-activity-stained gel in (c). The labels 1,2 and 3 in (c) indicate catalase-activity-staining bands.

We reasoned that if catalase activity was related to the culture cell density, then there would be a lowering of the peak of activity in cultures inoculated to progressively higher initial cell densities. Stationary phase cultures of $R$. leguminosarum were inoculated into fresh YEM medium at different inoculation densities ranging from $3 \times$ $10^{7}$ c.f.u. $\mathrm{ml}^{-1}$ to $7 \times 10^{8}$ c.f.u. $\mathrm{ml}^{-1}$. Fig. 5(a) shows a plot of catalase activity against time for cultures inoculated to densities (c.f.u. $\mathrm{ml}^{-1}$ ) of $6 \times 10^{7}, 2 \times 10^{8}$ and $4 \times 10^{8}$. It clearly shows that the peak of catalase activity, which occurs approximately $16 \mathrm{~h}$ after inoculation, was affected by initial culture density. Maximum catalase activity at $16 \mathrm{~h}$ was found in cultures inoculated to a density of $6 \times 10^{7}$ c.f.u. $\mathrm{ml}^{-1}\left(1 \cdot 11 \mu \mathrm{mol} \mathrm{O} \mathrm{min}^{-1}\right)$ while this maximum level fell to a minimum $(0.54 \mathrm{U})$ in cultures inoculated to $4 \times 10^{8}$ c.f.u. $\mathrm{ml}^{-1}$. We observed a narrow range of cell densities over which catalase activities were affected by cell densities and this is seen clearly in the plot of maximum catalase activity versus initial cell density in Fig. 5(b). We also found that catalase levels immediately after inoculation (the time zero sample points in Fig. 5a) were very sensitive to the inoculation density; the less dense the culture the higher the initial catalase activity. In earlier experiments, the differences in initial catalase levels were more pronounced than those observed in Fig. 5(a), but even when, as in this experiment, the culture samples were rapidly chilled and processed as quickly as possible, differences in the initial catalase activities were still seen. This indicates that catalase activity was induced very rapidly, the level of induction being cell-density dependent, following inoculation of cells into fresh medium.

\section{Stationary phase cultures of $\boldsymbol{R}$. leguminosarum contain an extracellular component that represses catalase activity}

We considered the possibility that repression of catalase activity resulted from the accumulation of an extracellular component in the culture medium during growth. Indeed, extracellular compounds have been found to be involved in regulating other cell-density-dependent phenomena in bacteria, including bioluminescence of Photobacterium and 




Fig. 4. Effect of growth phase on the sensitivity of $R$. leguminosarum to $\mathrm{H}_{2} \mathrm{O}_{2}$. Cultures were grown in $\mathrm{YEM}$ medium. Periodically samples were taken, challenged with $3 \mathrm{mM} \mathrm{H}_{2} \mathrm{O}_{2}$ and viability determined after $60 \mathrm{~min}$, relative to that of the sample before $\mathrm{H}_{2} \mathrm{O}_{2}$ addition. $O, \mathrm{OD}_{600} ; \square$ and $\square$, survival following $\mathrm{H}_{2} \mathrm{O}_{2}$ challenge from two separate experiments. Error bars indicate the standard deviation of assays done in duplicate.

Vibrio sp. (Meighan, 1991) and competence in Bacillus subtilis (Dubnau, 1991). This idea was tested by looking at the effects of filter-sterilized, spent culture medium from late-exponential cultures on the induction of catalase activity in freshly inoculated cultures. $R$. leguminosarum was inoculated, to an initial cell density of $2 \times$ $10^{8}$ c.f.u. $\mathrm{ml}^{-1}$, into $1000 \mathrm{ml}$ YEM medium or $750 \mathrm{ml}$ YEM plus $250 \mathrm{ml}$ spent culture medium. The spent culture medium was prepared by centrifuging off cells from a late-exponential phase culture and then filter sterilizing the remaining medium. Both cultures grew with similar doubling times, indicating that the spent medium did not contain anything toxic which affected growth rate, nor did it dilute out any essential nutrients to growth-limiting concentrations. Catalase activity was followed during the growth of these cultures for $32 \mathrm{~h}$ after inoculation during which time the cultures grew exponentially. The YEM control cultures showed the same kinetics of catalase induction, peaking approximately $16 \mathrm{~h}$ after inoculation (data not shown) and the graph obtained was almost identical to that already described in Fig. 5(a) for a culture inoculated to a density of $2 \times 10^{8}$ c.f.u. $\mathrm{ml}^{-1}$. However, in the culture containing $25 \%(\mathrm{v} / \mathrm{v})$ spent medium the initial catalase levels at 0 min were significantly lowered and were followed by a small initial decrease in catalase activity while levels did start to rise after $8 \mathrm{~h}$ and peak between 16 and $24 \mathrm{~h}$ after inoculation (Fig. 5a, broken line). The maximum activity attained was significantly lower than in the control cultures, and was comparable to the levels observed at the high inoculation cell densities. This result was highly reproducible and indicates that a compound accumulates in culture medium during exponential growth which
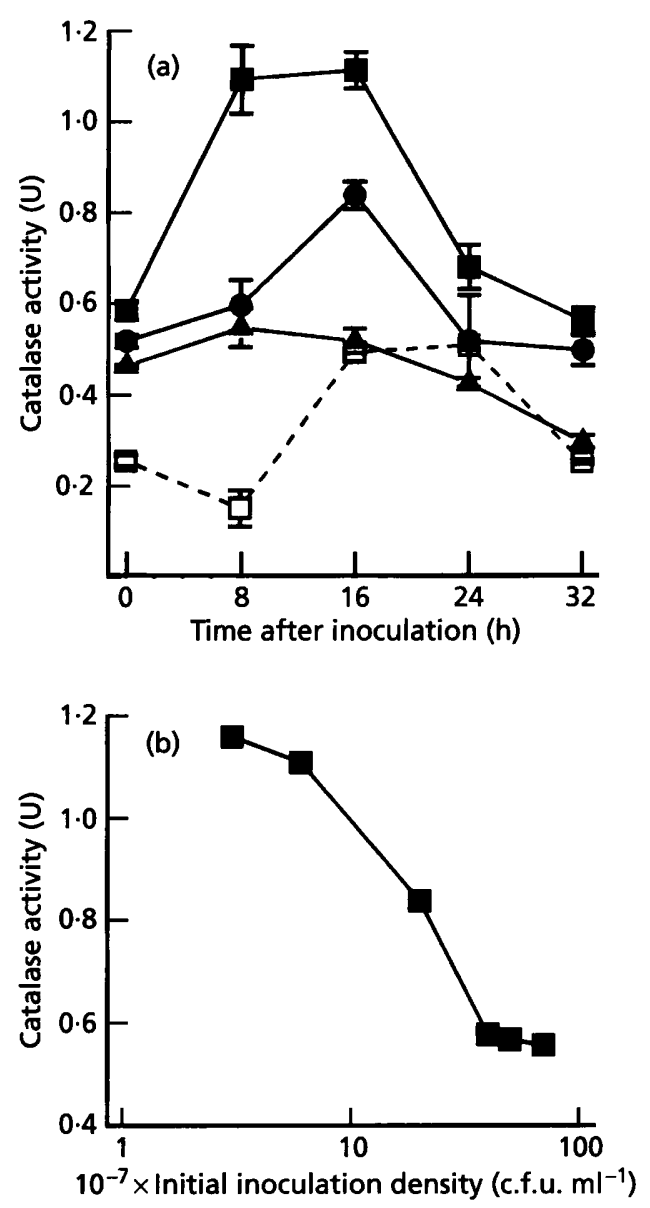

Fig. 5. Effect of initial inoculation density and the addition of spent culture medium on catalase activity of $R$. leguminosarum cultures. To look at the effect of inoculation density on catalase levels, cells were grown to early-stationary phase in YEM and then subcultured into fresh YEM to cell densities ranging from $3 \times 10^{7}$ to $7 \times 10^{8}$ c.f.u. $\mathrm{ml}^{-1}$. Samples were taken from cultures at time intervals for measurement of catalase activity. (a) Initial cell densities were $6 \times 10^{7}(\mathbb{D}), 2 \times 10^{8}(\mathrm{O})$, and $4 \times 10^{8}(\mathrm{~A})$. (b) Plot of the maximum catalase activity found in respective cultures (in all cases $16 \mathrm{~h}$ after inoculation) against the initial inoculation density of the culture. To determine the effect of the addition of spent culture medium on catalase activity, cells were grown to early-stationary phase in YEM medium and subcultured into fresh YEM medium containing spent culture medium $(25 \%, v / v)$, to an initial cell density of $2 \times 10^{8}$ c.f.u. $\mathrm{ml}^{-1}$. Samples were removed periodically during growth for catalase assay and the results are shown in (a) ( $\square$ and broken line). The spent culture medium was obtained from early-stationary-phase cultures growing in YEM medium as described in Methods.

directly or indirectly is able to repress catalase activity. It is likely that this is the reason for the catalase activity decreasing from the mid-exponential phase onwards (Fig. 3).

\section{Preliminary studies on the nature of the spent medium component}

To obtain some basic information on the nature of the spent medium component we examined the effect of 
Table 1. Effect of heat and pronase treatment on spentmedium-mediated catalase repression in $R$. leguminosarum

Catalase activity was measured in cultures $8 \mathrm{~h}$ after inoculation to $2 \times 10^{8}$ c.f.u. $\mathrm{ml}^{-1}$. For pronase treatment, spent medium was treated with pronase attached to agarose beads $\left(1 \mathrm{U} \mathrm{ml}^{-1}\right)$ (Sigma P4531) for $60 \mathrm{~min}$ at $37^{\circ} \mathrm{C}$. The beads were removed by centrifugation and the treated spent medium was filter sterilized. For heat treatment, spent medium was prepared as for pronase treatment and immediately heated at $100^{\circ} \mathrm{C}$ for $15 \mathrm{~min}$ before using in the experiment.

\begin{tabular}{|c|c|}
\hline $\begin{array}{l}\text { Addition to } \\
\text { YEM medium }\end{array}$ & $\begin{array}{c}\text { Catalase activity } \\
{\left[\mu \mathrm{mol} \mathrm{O}_{2} \mathrm{~min}^{-1}\right.} \\
\left.(\mathrm{mg} \text { protein })^{-1} \pm \mathrm{SD}\right]\end{array}$ \\
\hline None & $1.01 \pm 0.03$ \\
\hline $\begin{array}{l}\text { Spent medium } \\
(25 \%, v / v)\end{array}$ & $0.62 \pm 0.08$ \\
\hline $\begin{array}{l}\text { Pronase-treated } \\
\text { spent medium }\end{array}$ & $0.59 \pm 0.003$ \\
\hline $\begin{array}{l}\text { Heat-treated } \\
\text { spent medium }\end{array}$ & $0.53 \pm 0.021$ \\
\hline
\end{tabular}

various treatments on the ability of spent medium to repress catalase activity in early-exponential-phase cultures (initial cell density $2 \times 10^{8}$ c.f.u. $\mathrm{ml}^{-1}$ ). As the data in Table 1 indicate, the spent medium component is very heat resistant: $100{ }^{\circ} \mathrm{C}$ for 15 min causes no reduction in its ability to repress catalase activity. Similarly, treatment with pronase has no effect. Table 1 shows data for samples taken $8 \mathrm{~h}$ after inoculation and a similar trend was observed with samples taken at $16 \mathrm{~h}$ (data not shown). During attempts to dialyse the spent medium component we found that it lost all ability to repress catalase activity after storage at $4{ }^{\circ} \mathrm{C}$ for $24 \mathrm{~h}$; it also loses activity over a similar period of time at $25^{\circ} \mathrm{C}$ and at $-70{ }^{\circ} \mathrm{C}$. It seems that the component(s) in the spent growth medium is a heat resistant, non-proteinaceous molecule which nevertheless undergoes slow inactivation on storage.

\section{DISCUSSION}

In this study, we have shown that R. leguminosarum bv. phaseoli adapts to $\mathrm{H}_{2} \mathrm{O}_{2}$ stress. This showed the typical features of a bacterial response to environmental stress in that adaptation of $\mathrm{R}$. leguminosarum to normally lethal levels of the stress $\left(3 \mathrm{mM} \mathrm{H} \mathrm{H}_{2} \mathrm{O}_{2}\right)$ could be achieved by pretreatment with sublethal levels of the stress $(200 \mu \mathrm{M}$ $\mathrm{H}_{2} \mathrm{O}_{2}$ ). The involvement of new protein synthesis in this adaptation was demonstrated by the inhibitory effect of the protein synthesis inhibitor chloramphenicol on adaptation. This adaptive response is similar to those previously described for enteric bacteria (Christman et al., 1985; Demple \& Halbrook, 1983), B. subtilis (Dowds et al., 1987) and yeast (Collinson \& Dawes, 1992; Jamieson, 1992). Increased resistance of $R$. leguminosarum to $\mathrm{H}_{2} \mathrm{O}_{2}$ was correlated with a twofold increase in catalase activity in cells treated with a non-lethal dose of $\mathrm{H}_{2} \mathrm{O}_{2}$. This compares to four- to fivefold and two- to fourfold increases in the catalase activities of $S$. typhimurium and E. coli, respectively, when they were treated with adaptive $\mathrm{H}_{2} \mathrm{O}_{2}$ concentrations (Christman et al., 1985; Demple \& Halbrook, 1983).

During these studies, we observed that induction of catalase activity through the $R$. leguminosarum growth curve had distinctive kinetics. Following inoculation of fresh growth medium the catalase activity of the growing culture increased rapidly to a prominent maximum approximately $16 \mathrm{~h}$ (approx. three doubling times) after inoculation when the culture was still in the early- to midexponential growth phase. The catalase activity of the culture then declined rapidly so that by late-exponential phase it had reached a value only $25-33 \%$ of its maximum. The levels then remained at this low level throughout late-exponential and stationary phase. This observation is striking because it is very different to the kinetics of catalase induction in cultures of E. coli and S. typhimurium. In these enteric bacteria, catalase levels increase throughout exponential phase to a maximum in stationary phase (Finn \& Condon, 1975; Hassan \& Fridovich, 1978) and this correlates with stationary phase cells being more resistant to oxidative stress.

Similar observations have been made in Haemophilus parainfluenzae, Rhodobacter sphaeroides and the yeast Saccbaromyces cerevisiae and in all cases catalase activities increase at the onset of and during stationary phase (Clayton, 1960; Kwiek et al., 1970; White, 1962). Does it follow, therefore, that $R$. leguminosarum cultures have a very low resistance to $\mathrm{H}_{2} \mathrm{O}_{2}$ in stationary phase? The answer based on the data in Fig. 4 is clearly no. Our data show that $R$. leguminosarum also greatly increases its resistance to $\mathrm{H}_{2} \mathrm{O}_{2}$-mediated oxidative stress in stationary phase. However, the implication from these data is that alternative protective mechanisms against $\mathrm{H}_{2} \mathrm{O}_{2}$ must be induced in the latter stages of exponential growth and stationary phase of $R$. leguminosarum. Catalase is used at low cell densities, earlier in the growth cycle, but protective mechanisms other than catalase are presumably much more important in protecting late-exponential and stationary phase cultures and their induction reduces the burden on catalase activity so its levels can be reduced.

We hypothesized that the catalase induction kinetics of $R$. leguminosarum reflected a phenomenon related to cell density. The maximum level of catalase expression during growth was acutely affected by cell density, with maximum catalase activity at low initial cell densities, so it is reasonable to propose that catalase levels decline in lateexponential phase cultures because of the increase in culture cell density. Therefore, control of catalase activity levels in $R$. leguminosarum cultures joins a number of other bacterial processes in being regulated in response to cell density. The best known example of what has recently been called quorum sensing (Fuqua et al., 1994) is regulation of bacterial bioluminescence in Vibrio fischeri and Photobacterium (Meighen, 1991). In addition, Streptomyces sporulation (Kaiser \& Losick, 1993; Willey et al., 1991), competence and sporulation in Bacillus (Dubnau, 1991; Grossman \& Losick, 1988), and regulation of virulence factors in Pseudomonas aeruginosa (Passador $e t$ al., 
1993) are all examples of density-regulated phenomena. However, in each of these examples expression of the target activity is increased at high cell density, the converse to what we observe in catalase regulation in $R$. leguminosarum. What each of these cell-density-regulated phenomena have in common is that they are controlled by extracellular molecules which accumulate in cultures at high cell densities. Bioluminescence in $V$. fischeri is switched on at high cell densities as a consequence of the accumulation of an autoinducer, $\mathrm{N}$-(3 oxohexanoyl)-Lhomoserine lactone (Meighen, 1991; Bainton et al., 1992). This molecule is capable of diffusing freely across the membrane and is excreted into the medium; it induces luminescence at the level of gene expression by a positive feedback mechanism (Kaiser \& Losick, 1993; Meighen, 1991). In this, and in other density-related phenomena, the bacteria actually respond to the presence of other cells, or more precisely to the presence of a substance produced by other cells in the culture medium. It is significant, therefore, that we have demonstrated the accumulation of an unidentified compound in spent culture medium from early-stationary-phase cultures of $R$. leguminosarum which represses catalase activity when added to freshly inoculated cultures. Our data support the idea that during cell growth this compound accumulates and directly or indirectly represses catalase activity.

Of particular interest to our study is the work of Shapiro (1992) on the differential expression of DNA polymerase I (PolI) during E. coli colony development. The induction of Poll is a density-dependent phenomenon. Its expression is maximal during the early stages of microcolony development when it is needed to prevent DNA damage (SOS induction) and to promote normal cell morphogenesis (Shapiro, 1992). Shapiro hypothesized that early in colony development PolI is induced because it is required to repair oxidative damage to the genome and therefore prevents damage reaching levels which would require the SOS response. Later in colony development he showed that diffusible substances accumulate which switch off its expression presumably as a consequence of the elimination of the need for DNA repair involving PolI, perhaps by decreasing oxidative stress by creating a reducing environment (Shapiro, 1992). The induction of Poll in a density-dependent manner, early in colony development, has clear parallels with the induction of catalase activity in liquid cultures of $R$. leguminosarum reported in this paper. PolI is induced early in E. coli colony development, when it is hypothesized oxidative stress is high, to repair DNA damage. Catalase is induced early in liquid cultures of $R$. leguminosarum but falls off in later stages of growth. We have demonstrated here the accumulation of a diffusible substance in the later stages of $R$. leguminosarum growth in liquid cultures which represses catalase activity. The extracellular, spent medium component is a heat-stable compound which is probably neither a protein nor a peptide as it is insensitive to protease treatment (Table 1). This extracellular component might be a signal molecule analogous to the bioluminescence autoinducer which signals the population to switch off catalase and possibly switch on some other oxidative stress protection system. A second possibility is that the extracellular compound is an antioxidant molecule which may indirectly affect catalase activity by reducing the level of oxidative stress as cell densities increase, thereby reducing the need for high catalase activity. We are currently investigating this possibility.

These findings imply that there might be some cooperativity, or quorum sensing (Fuqua et al., 1994), between R. leguminosarum cells in controlling a population response to the threat posed by oxidative stress. There are potential advantages to a Rbizobium population of having an extracellular $\mathrm{H}_{2} \mathrm{O}_{2}$ protection mechanism, especially in dense cultures. $\mathrm{H}_{2} \mathrm{O}_{2}$ is a neutral molecule and is able to freely diffuse across bacterial cell membranes. Therefore, its presence constitutes a problem to entire bacterial populations and not just to individual bacteria. The major cellular damage caused by $\mathrm{H}_{2} \mathrm{O}_{2}$ is thought to be due to the formation of hydroxyl free radicals by reaction with reduced transition metals via Fenton reactions (Halliwell \& Gutteridge, 1989). While within a bacterial cell the concentration of free transition metals is low, this will not always be the case in the extracellular environment, including laboratory media. An extracellular, multicellular $\mathrm{H}_{2} \mathrm{O}_{2}$ scavenging system would minimize such problems. A case for a multicellular antioxidant defence, albeit involving catalase, has experimental support from recent experiments on E. coli (Ma \& Eaton, 1992). It was found that dilute suspensions of catalase-positive E. coli were as easily killed by exogenous $\mathrm{H}_{2} \mathrm{O}_{2}$ as catalase mutants, but catalase-positive strains were protected against $\mathrm{H}_{2} \mathrm{O}_{2}$ killing in high density cultures or colonial bacteria. Ma \& Eaton (1992) argued that the highly diffusible nature of $\mathrm{H}_{2} \mathrm{O}_{2}$ means that individual bacteria cannot maintain an internal/external concentration gradient of the oxidant, but that at high cell densities the $\mathrm{H}_{2} \mathrm{O}_{2}$ levels can be sufficiently reduced by catalase activity to benefit the population.

Extracellular communication is, of course, not a new observation in Rhizobium biology. Communication between the plant and the bacterial partners of the nitrogenfixing symbiosis is mediated in part by low molecular mass signal molecules (Long, 1989; Spaink et al., 1991). The observation of this cell-density phenomenon in $R$. leguminosarum begs the question of whether this extracellular compound has a role in the high-cell-density environment of the root nodule and plays a role in protecting bacteroids against oxidative damage. The importance of protecting nitrogenase against inactivation by $\mathrm{O}_{2}$ and the mechanisms which achieve its protection is well documented (Appleby, 1994; Hill, 1988). Less attention has been given to the possibility of generating reactive oxygen species in nodules and their unique potential for damaging bacteroids. Interestingly, the production by the plant partner in the soybeanBradyrhizobium japonicum symbiosis of oxidative protection enzymes in the nodule tissue is positively correlated with the increase in nitrogenase activity and leghaemoglobin content (Dalton et al., 1986), indicating that the developing nodule is in an environment of increasing oxidative stress. 


\section{ACKNOWLEDGEMENTS}

This work was supported by a grant from the United Kingdom AFRC, grant no. (NI) PG28/546. H.D.W. gratefully acknowledges the advice given by Cyril Appleby and Allan Downie.

\section{REFERENCES}

Appleby, C. A. (1984). Leghaemoglobin and Rbizobium respiration. Annu Rev Plant Pbysiol 35, 443-478.

Bainton, N. J., Bycroft, B. W., Chabra, S. R., Stead, P., Gledhill, L., Hill, P. J., Rees, C. E. D., Winson, M. K., Salmond, G. P. C., Stewart, G. S. A. B. \& Williams, P. (1992). A general role for the lux autoinducer in bacterial cell signalling: control of antibiotic biosynthesis in Erwinia. Gene 116, 87-91.

Brot, N., Weissbach, L., Werth, J. \& Weisbach, H. (1981). Enzymatic reduction of protein-bound methionine sulfoxide. Proc Natl Acad Sci US A 78, 2155-2158.

Chance, B., Sies, H. \& Boveris, A. (1978). Hydroperoxide metabolism in mammalian organs. Pbysiol Rev 59, 527-605.

Christman, M. F., Morgan, R. W., Jacobson, F. S. \& Ames, B. N. (1985). Positive control of a regulon for defenses against oxidative stress and some heat-shock proteins in Salmonella typhimurium. Cell 41, 753-762.

Christman, M. F., Storz, G. \& Ames, B. N. (1989). OxyR, a positive regulator of hydrogen peroxide-inducible genes in Escherichia coli and Salmonella typhimurium, is homologous to a family of bacterial regulatory proteins. Proc Natl Acad Sci US A 86, 3484-3488.

Clare, D. A., Duong, M. N., Darr, D., Archibald, F. \& Fridovich, I. (1984). Effects of molecular oxygen on detection of superoxide radical with nitroblue tetrazolium and on activity stains for catalase. Anal Biochem 140, 532 537.

Clayton, R. K. (1960). The induced synthesis of catalase in Rhodopseudomonas sphaeroides. Biochim Biophys Acta 37, 503-512.

Collinson, L. P. \& Dawes, I. W. (1992). Inducibility of the response of yeast cells to peroxide stress. J Gen Microbiol 138, 329-335.

Dalton, D. A., Russell, S. A., Hanus, F. J., Pascoe, G. A. \& Evans, H. J. (1986). Enzymatic reactions of ascorbate and glutathione that prevent peroxide damage in soybean root nodules. Proc Natl Acad Sci US A 83, 3811-3815.

Demple, B. (1991). Regulation of bacterial oxidative stress genes. Annu Rev Genet 25, 315-337.

Demple, B. \& Halbrook, J. (1983). Inducible repair of oxidative DNA damage in Escherichia coli. Nature 304, 466-468.

Demple, B. \& Linn, S. (1982). 5,6-Saturated thymine lesions in DNA production by ultraviolet light and hydrogen peroxide. Nucleic Acids Res 10, 3781-3789.

Dowds, B. C. A., Murphy, P., McConnell, D. J. \& Devine, K. M. (1987). Relationship among oxidative stress, growth cycle and sporulation in Bacillus subtilis. J Bacteriol 169, 5771-5775.

Dubnau, D. (1991). Genetic competence in Bacillus subtilis. Microbiol Rev 55, 395-424.

Farr, S. \& Kogoma, T. (1991). Oxidative stress responses in Eschericbia coli and Salmonella typhimurium. Microbiol Rev 55, 561-585.

Finn, G. J. \& Condon, S. (1975). Regulation of catalase synthesis in Salmonella typhimurium. J Bacteriol 123, 570-579.

Fuqua, W. C., Winans, S. C. \& Greenberg, E. P. (1994). Quorum sensing in bacteria: the LuxR-LuxI family of cell density-responsive transcriptional regulators. J Bacteriol 176, 269-275.

Fridovich, I. (1978). The biology of oxygen radicals. Science 201, $875-880$
Graham, P. H. (1992). Stress tolerance in Rhizobium and Bradyrbizobium, and nodulation under adverse soil conditions. Can $J$ Microbiol 38, 475-484.

Greenberg, J. T. \& Demple, B. (1989). A global response induced in Escherichia coli by redox-cycling agents overlaps with that induced by peroxide stress. J Bacteriol 171, 3933-3939.

Grossman, A. D. \& Losick, R. (1988). Extracellular control of spore formation in Bacillus subtilis. Proc Natl Acad Sci US A 85, 4369-4373.

Halliwell, B. \& Gutteridge, J. M. C. (1989). Free Radicals in Biology and Medicine. Oxford: Clarendon Press.

Hassan, H. M. \& Fridovich, I. (1978). Regulation of the synthesis of catalase and peroxidase in Escherichia coli. J Biol Chem 253, $6445-6450$.

Hill, S. (1988). How is nitrogenase regulated by oxygen? FEMS Microbiol Rev 54, 111-130.

Jamieson, D. J. (1992). Saccharomyces cerevisiae has distinct adaptive responses to both hydrogen peroxide and menadione. I Bacteriol 174, 6678-6681.

Kaiser, D. \& Losick, R. (1993). How and why bacteria talk to each other. Cell 73, 873-885.

Kwiek, S., Gabrys, A. \& Lorenc, R. (1970). Dependence of the activity of yeast catalase on yeast growth phases and culture conditions. Acta Microbiol Pol Ser B 2, 111-114.

Long, S. R. (1989). Rbizobium-legume nodulation: life together in the underground. Cell 56, 203-214.

Levin, D. E., Hollstein, M., Christman, M. F., Schwiers, E. A. \& Ames, B. N. (1982). A new Salmonella tester strain (TA102) with AT base pairs at the site of mutation detects oxidative mutagens. Proc Natl Acad Sci USA 79, 7445-7449.

Ma, M. \& Eaton, J.W. (1992). Multicellular oxidant defence in unicellular organisms. Proc Natl Acad Sci US A 89, 7924-7928.

Markwell, M. A. K., Haas, S. M., Bieber, L. L. \& Tolbert, N. F. (1978). A modification of the Lowry procedure to simplify protein determination in membrane and lipoprotein samples. Anal Biochem 87, 206-210.

Meighen, E. A. (1991). Molecular biology of bacterial bioluminescence. Microbiol Rev 55, 123-142.

Nystrom, T. (1993). In Starvation in Bacteria, pp. 129-150. Edited by S. Kjelleberg. New York: Plenum.

Passador, L., Cook, J. M., Gambello, M. J., Rust, L. \& Iglewski, B. H. (1993). Expression of Pseudomonas aeruginosa virulence genes requires cell-to-cell communication. Science 260, 1127-1130.

Rorth, M. \& Jensen, P. K. (1967). Determination of catalase activity by means of the Clark electrode. Biochim Biophys Acta 139, 171-173.

Shapiro, J. A. (1992). Differential action and differential expression of DNA polymerase I during Escherichia coli colony development. $J$ Bacteriol 174, 7262-7272.

Siegle, D. A. \& Kolter, R. (1992). Life after log. J Bacteriol 174, 345-348.

Spaink, H. P., Sheeley, D. M., Van Brussel, A. A. N., Glushka, J., York, W. S., Tak, T., Geiger, O., Kennedy, E. P., Reinhold, V. N. \& Lugtenberg, B. J. J. (1991). A novel, highly unsaturated, fatty acid moiety of lipopolysaccharide signals determines host specificity of Rhizobium leguminosarum. Nature 354, 125-130.

Storz, G., Tartaglia, L. A., Farr, S. B. \& Ames, B. (1990). Bacterial defenses against oxidative stress. Trends Genet 6, 363-368.

Vincent, J. M. (1970). A Manual for the Practical Study of Root-nodule Bacteria. Oxford: Blackwell.

White, D. C. (1962). Cytochrome and catalase patterns during growth of Haemopbilus parainfluenzae. J Bacteriol 83, 851-859. 
Willey, J., Santamaria, R., Guijarro, J., Geistlich, M. \& Losick, R. (1991). Extracellular complementation of a developmental mutation implicates a small sporulation protein in aerial mycelium formation by $S$. coelicolor. Cell 65, 641-650.

Williams, H. D., Appleby, C. A. \& Poole, R. K. (1990). The unusual behaviour of the putative terminal oxidases of Bradyrbizobium japonicum bacteroids revealed by low-temperature photodissociation studies. Biochim Biophys Acta 1019, 225-232.

Received 2 August 1994; revised 15 November 1994; accepted 22 November 1994. 